\title{
Natural Antidiabetic of Tunjuk Langit (Helminthostachys zeylanica) Rhizome Extracts
}

\author{
Fania E. Ridhasya ${ }^{1}$, Muhammad Almurdani ${ }^{1}$, Rudi Hendra ${ }^{1,2}$, Hilwan Y. Teruna ${ }^{1,2}$ \\ ${ }^{1}$ Department of Chemistry, Faculty of Mathematics and Natural Sciences, \\ University of Riau Pekanbaru, Riau, Indonesia \\ ${ }^{2}$ Scientific Consortium of Drug Discovery and Development, \\ University of Riau, Pekanbaru, Riau, Indonesia
}

\begin{abstract}
The use of medicinal plants in treating diabetes mellitus is increasing in Indonesia. Plenty of plants from different regions may have antidiabetic effect, including Helminthostachys zeylanica. This plant is commonly used as a traditional medicine to treat inflammation, cough, dysentery, and malaria in Talang Mamak tribe, Indragiri Hulu, Riau, however in China it is used to treat diabetic. Thus, we examined whether the extract of $H$. zeylanica originated from Riau have potential antidiabetic activity. We assessed the $\alpha$-glucosidase inhibitory activity of the extract of $\mathrm{H}$. zeylanica rhizome. The results showed the antidiabetic values of n-hexane, dichloromethane (DCM), ethyl acetate (EtOAc), methanol (MetOH), and ethanol (EtOH) extracts were $380.88 \pm 0.09 ; 190.76 \pm 0.22 ; 61.18 \pm 0.59 ; 47.86 \pm 0.06$; and $60.78 \pm 0.02$, respectively. Acarbose were used as standard with antioxidant values of $19.73 \pm 0.07$. It can be concluded that the methanol extract is potential to be proposed as antidiabetic.
\end{abstract}

Keywords: $\alpha$-glucosidase, antidiabetic, $H$. zeylanica

\section{Introduction}

Diabetes is a chronic metabolic disease which is caused by abnormalities in insulin action. Chronic hyperglycemia in diabetes can cause degenerative in several organ such as kidney, retina etc. There are various medications to treat diabetes mellitus such as gene therapy, insulin, and antidiabetic drugs. However, antidiabetic drugs possess adverse reactions. Therefore, an alternative medicine with less adverse reaction is needed. ${ }^{1}$ Different tribes in Indonesia have been using plants to treat various diseases. Talang Mamak tribe in
Riau use $H$. zeylanica to treat inflammation, dysentery, cataracts, early-stage tuberculosis, syphilis, diabetic, and malaria. ${ }^{2}$

H. zeylanica contains saponins, flavonoids, stilbenes and phenolics and shows various biological activities such as antioxidant, ${ }^{3,4,5}$ anti-inflammation, ${ }^{6,7,8}$ anti-osteoporotic, ${ }^{9}$ and antihyperuricemia. ${ }^{10}$ Furthermore, phenolics and flavonoids inhibit $\alpha$-glucosidase enzyme which is responsible in glucose levels. ${ }^{11}$ Therefore, we studied whether the extracts of $H$. zeylanica originated from Riau have

Corresponding author: Hilwan Y. Teruna. Department of Chemistry, Faculty of Mathematics and Natural Sciences, Univerisity of Riau, Pekanbaru. Email: hyteruna@1ecturer.unri.ac.id

Received: 18 October 2019. Revised: 10 December 2019. Published: 20 December 2019. 
potential antidiabetic activity. The results of this study may be beneficial for the use of $H$. zeylanica as an antidiabetic drug.

\section{Material and Methods}

Extract Preparation

H. zeylanica were collected in Kelayang District, Indragiri Hulu Regency, Riau Province. Rhizome dried powder (100 g) were cold extracted using $\mathrm{n} \neg$-hexane, dichlorometane, ethyl acetate (EtOAc), methanol $(\mathrm{MeOH})$, and ethanol $(\mathrm{EtOH})$, respectively, and filtered. $10 \mathrm{~mL}$ of filtrate was prepared for antidiabetic assay.

\section{In vitro $\alpha$-glucosidase inhibition assay}

Enzyme solution was prepared by dissolving $1 \mathrm{mg}$ of $\alpha$-glucosidase in $100 \mathrm{~mL}$ of phosphate buffer ( $\mathrm{pH} \mathrm{7}$ ) which contained $200 \mathrm{mg}$ of bovine serum albumin. Prior to use, $1 \mathrm{~mL}$ of enzyme solution was diluted 25 times with phosphate buffer ( $\mathrm{pH} 7)$. The reaction mixture was prepared in the microplate wells which consisted of $25 \mu \mathrm{l}$ of $20 \mathrm{mM}$ p-nitrophenylD-glucopyranose as substrate and $50 \mu \mathrm{l}$ of $100 \mathrm{mM}$ phosphate buffer ( $\mathrm{pH}$ 7). Briefly, each extract was dissolved in DMSO and aliquots of samples $(10 \mu \mathrm{L})$ was added to the reaction mixture to final concentrations of: $31.25 \mu \mathrm{g} / \mathrm{mL}, 62.5 \mu \mathrm{g} / \mathrm{mL}, 125 \mu \mathrm{g} / \mathrm{mL}, 250$ $\mu \mathrm{g} / \mathrm{mL}, 500 \mu \mathrm{g} / \mathrm{mL}, 1000 \mu \mathrm{g} / \mathrm{mL}$. Solution of $1 \%$ acarbose (Glucobay ${ }^{\circledR}$ ) was prepared with phosphate buffer $\mathrm{pH}$ 7. Then it was mixed with $2 \mathrm{~N} \mathrm{HCl}$ of equal volume (1:1) and was centrifuged. Aliquots of supernatant $(10 \mu \mathrm{L})$ was taken and added into the reaction mixture at final concentration of $0.0625 \mu \mathrm{g} / \mathrm{mL} ; 0.125$ $\mu \mathrm{g} / \mathrm{mL} ; 0.25 \mu \mathrm{g} / \mathrm{mL} ; 0.5 \mu \mathrm{g} / \mathrm{mL}$; and $1 \mu \mathrm{g} /$ $\mathrm{mL}$. Blanks, controls and each concentration of samples were done in triplicate. The mixture was incubated at $37^{\circ} \mathrm{C}$ for 5 minutes, and then $25 \mu$ of enzyme solution was added into the reaction mixture and incubated further for 15 minutes. Enzyme reaction was stopped by adding $100 \mu \mathrm{L}$ of $0.1 \mathrm{M} \mathrm{Na} 2 \mathrm{CO} 3$. Blanks, controls, and samples absorbance of the p-nitrophenol product was measured by microplate reader spectrophotometer at 410 nm wavelength.

\section{Results and Discussion}

The result is presented in Table 1 .

The $\alpha$-glucosidase inhibition activity was conducted based on the basic principle of enzymatic reaction, the hydrolysis of p-nitrophenyl- $\alpha$-D-glucopiranoside (PNPG) substrate by the $\alpha$-glucosidase enzyme to p-nitrophenol (yellow color) and glucose. ${ }^{11}$ We found that $\mathrm{MetOH}$ extract has the highest antidiabetic activity, weaker than acarbose. Acarbose is an antidiabetic drug that works by inhibiting the activity of the $\alpha$-glucosidase enzyme in compete directly with polysaccharides to cover the active side of the enzyme. ${ }^{12}$ Thus, we propose that

Table 1. Antidiabetic Activity of Extracts from H.zeylanica

\begin{tabular}{ll}
\hline \multicolumn{1}{c}{ Sample } & IC50 $(\boldsymbol{\mu g} / \mathbf{m L})$ \\
\hline n-hexane extract & $380.88 \pm 0.09$ \\
DCM extract & $190.76 \pm 0.22$ \\
EtOAc extract & $61.18 \pm 0.59$ \\
MetOH extract & $47.86 \pm 0.06$ \\
EtOH extract & $60.78 \pm 0.02$ \\
Acarbose & $19.73 \pm 0.07$ \\
\hline
\end{tabular}


MetOH extract of $H$. zeylanica might have similar activity with that of acarbose.

H. zeylanica contains various flavonoid compounds $^{3}$ that have ability to inhibit $\alpha$-glucosidase enzymes. ${ }^{13}$ Inhibition of $\alpha$-glucosidase activity by various phenolic compounds has been widely explained in the literature. $\alpha$-glucosidase is effectively inhibited by flavonols, ${ }^{11}$ luteolin, myricetin, and quercetin. ${ }^{14}$

\section{Conclusion}

The methanol extract of $H$. zeylanica rhizome might be potential in inhibiting $\alpha$-glucosidase (IC50 $47.86 \pm 0.06 \mathrm{ppm}$ ). Therefore, this plant can be proposed as antidiabetic medicine.

\section{Acknowledgments}

Authors thank to all colleagues who fully supported this research.

\section{Funding}

This study was funded by Postgraduate Research Grant from the Ministry of Research, Technology, and Higher Education of the Republic of Indonesia 2019 with contract number: 808/UN.19.5.1.3/ PT.01.03/2019.

\section{Conflict of Interest}

None declared.

\section{References}

1. Aquarista NC. Perbedaan karakteristik penderita diabetes melitus tipe 2 dengan dan tanpa penyakitjantung koroner.Jurnal Berkala Epidemiologi. 2017;4(1):37-47.

2. Hartini S. Helminthostachys zeylanica (L.) Hook: Potensinya Sebagai Obat Masa Depan. Warta Kebun Raya. 2011;11(1):34-37.

3. Huang YL, Yeh PY, Shen CC, Chen CC. Antioxidant flavonoids from the rhizomes of Helminthostachys zeylanica. Phytochemistry. 2003;64(7):1277-1283.
4. Chen CC, Huang YL, Yeh PY, Ou JC. Cyclized Geranyl Stilbenes from the Rhizomes of Helminthostachys zeylanica. Planta Medica. 2003;69(10):964-967.

5. Fitrya, Anwar L, Eliza, Muharni. Ugonin J Flavonoid From Tunjuk Langit (Helminthostachys zeylanica Linn.) Root Extract. Indonesian Journal of Chemistry. 2010;10(2):233-238.

6. Huang YC, Hwang $T$, Chang $C$, Yang Y, Shen C, Liao W, Liaw C. Anti-inflammatory Flavonoids from the Rhizomes of Helminthostachys zeylanica. Journal of Natural Products. 2009;72(7):1273-1278.

7. Chen C, Yang C, Tsai Y, Liaw C, Chang W, Hwang T. Ugonin U stimulates NLRP3 inflammasome activation and enhances inflammasome-mediated pathogen clearance. Redox Biology. 2017;11: 263 274.

8. Su L, Li Y, Li H, Dai W, Liu D, Cao L, Li R. Anti-inflammatory Prenylated Flavonoids from Helminthostachys zeylanica. Chemistry Pharmacy Bulletin. 2016;64(5):497-501.

9. Huang Y, Shen C, Shen Y, Chiou W, Chen C. Anti-inflammatory and Antiosteoporosis Flavonoids from the Rhizomes of Helminthostachys zeylanica. Journal of Natural Products. 2017;80:246-253.

10. Fitrya, Muharni. An Antihyperuricemia Effect of Ethanol Extract of Tunjuk Langit Rhizome (Helmynthostachys Zeylanica Linn Hook) on Swiss Male Mice. Traditional Medicine Journal. 2014;19(January):14-18.

11. LiKB, ChanKY.Production and properties of alpha-glucosidase from Lactobacillus acidophillus. Applied Environmental Microbiology. 1983;46(6):1380-1387.

12. Lee S, Lin H, Chen C. Acylated Flavonol Monorhamnosides $\alpha$-glucosidase Inhibitors, from Machilus philippinensis. 
Phytochemistry. 2008;69:2347-2353.

13. Wang H, Du Y, Song H. $\alpha$-Glucosidase and $\alpha$-amylase inhibitory activities of guava leaves. Food Chemistry. 2010;123(1):613.

14. Tadera K, Minami Y, Takamatsu K, Matsuoka T. Inhibition of $\alpha$-Glucosidase and $\alpha$-Amylase by Flavonoids. Journal of Nutritional and Vitaminology. 2006;52(2):149-153. 